Received: 20-60-2019

Revised: 08-07-2019

Published: 15-10-2019

\title{
PENINGKATAN KEMAMPUAN PEMECAHAN MASALAH MATEMATIS MELALUI MODEL PEMBELAJARAN LAPS-HEURISTIK
}

\author{
Gilang Azwardi ${ }^{1}$, Rani Sugiarni ${ }^{2}$ \\ ${ }^{1,2}$ Jurusan Pendidikan Matematika, Universitas Suryakancana, Cianjur \\ 1 gilangazwardi@gmail.com \\ 22ranisugiarni@gmail.com
}

\begin{abstract}
Abstrak: Penelitian ini bertujuan untuk menjawab apakah setelah penerapan model LAPSHeuristic (Logan Avenue Problem Solving) dapat meningkatkan kemampuan pemecahan masalah matematis siswa pada materi trigonometri di kelas X SMA Negeri 1 Cibeber. Jenis penelitian kuantitatif tipe Quasi Experimen dengan bentuk Design The Non equivalent Pre testPost test Control Group Design. Populasi dalam penelitian ini adalah siswa kelas X IPA SMAN 1 Cibeber. Adapun penelitian ini dipilih sebanyak 2 kelas dari 3 kelas melalui teknik purposive sampling dan melibatkan sampel sebanyak 53 orang yang berasal dari dua kelas yang dipilih. Kelas X IPA 2 dipilih sebagai kelas eksperimen yang memperoleh pembelajaran dengan model LAPS-Heuristik dan kelas X IPA 1 dipilih sebagai kelas kontrol yang memperoleh pembelajaran biasa. Untuk mendapatkan data hasil penelitian digunakan instrument berupa tes kemampuan pemecahan masalah matematis siswa dan kuisioner sikap siswa. Pengolahan data hasil penelitian ini menggunakan software SPSS versi 20. Berdasarkan hasil analisis data penelitian kemampuan pemecahan masalah matematis siswa dengan menggunakan model pembelajaran LAPS-Heuristic lebih baik dibandingkan menggunakan model pembelajaran biasa. Sikap siswa terhadap pembelajaran matematika dengan menggunakan model LAPS-Heuristic (Logan Avenue Problem Solving) sebagian besar positif.

Kata kunci: Model LAPS-Heuristic; Kemampuan Pemecahan Masalah Matematis.
\end{abstract}

\begin{abstract}
This study aims to answer whether after the application of the LAPS-Heuristic model (Logan Avenue Problem Solving) can improve students' mathematical problem solving abilities in trigonometric material in class X of SMA 1 Cibeber. Quantitative research type Quasi Experiment with the design form The Nonequivalent Pre test-Post test Control Group Design. The population in this study were students of class X IPA SMAN 1 Cibeber. The research was chosen by 2 classes from 3 classes through a purposive sampling technique and involved a sample of 53 people from two select classes. Class X IPA 2 was chosen as the experimental class which obtained learning with the LAPS-Heuristic model and class X IPA 1 was chosen as the control class that received regular learning. To get the data the results of the study used instruments in the form of tests of students' mathematical problem solving abilities and student attitude questionnaires. Data processing results of this study using SPSS version 20. Based on the results of data analysis research students' mathematical problem solving ability using the LAPS-Heuristic learning model is better compared using ordinary learning models. Students' attitudes toward learning mathematics using the LAPS-Heuristic model (Logan Avenue Problem Solving) are mostly positive.
\end{abstract}

Keywords: LAPS-Heuristic Model; Mathematical Problem Solving Ability.

\section{Pendahuluan}

Keberhasilan dari sebuah pembelajaran tidak hanya diwujudkan dalam sebuah hasil prestasi siswa, namun pembelajaran yang berhasil adalah pembelajaran yang mampu mengembangkan apa yang telah dipelajari dan mengaplikasikan di kehidupan sehari-hari. Matematika adalah pelajaran yang sering ada dari 
tiap tingkatan, karena matematika itu penting bagi kita. Pembelajaran matematika di sekolah tidak hanya ditujukan pada peningkatan kemampuan siswa dalam berhitung atau menerapkan rumus/ prosedur dalam menyelesaikan soal-soal rutin saja, tetapi pada peningkatan kemampuan siswa dalam pemecahan masalah, baik masalah matematika maupun masalah lainnya yang menggunakan matematika untuk memecahkannya. Menurut Abdurrahman (2003) "matematika adalah bahasa simbol yang fungsi praktisnya untuk mengekspresikan hubungan-hubungan kuantitatif dan keruangan sedangkan fungsinya adalah untuk memudahkan berfikir". Adapun NCTM (2000) merumuskan lima standar kemampuan matematika yang harus dimiliki siswa, yaitu kemampuan pemecahan masalah (problem solving), kemampuan penalaran dan pembuktian (reasoning and proof), kemampuan komunikasi (communication), kemampuan koneksi (connections), dan kemampuan representasi (representations).

Kemampuan masalah matematis adalah kemampuan memahami masalah, merencanakan strategi dan prosedur pemecahan masalah, melakukan prosedur pemecahan masalah, memeriksa kebenaran jawaban dan hasil siswa diperoleh serta menulis jawaban akhir sesuai permintaan soal. Kemampuan pemecahan masalah dalam matematika sangat diperlukan. Pemecahan masalah adalah suatu cara atau strategi untuk mewujudkan harapan sesuai dengan prosedur yang baik dan benar, mampu mengatasi soal-soal yang sulit dengan cara mengerahkan segala kemampuan yang dimiliki sehingga menuntut siswa untuk dapat berpikir kreatif dan efisien. Pemecahan masalah salah satu kemampuan yang harus dikuasai setelah belajar matematika, karena sesuai dengan pendapat Yulianto dkk (2019) pemecahan masalah lebih mengutamakan proses dan strategi yang dilakukan dalam penyelesaian masalah daripada hanya sekedar hasil dikarenakan akan berdampak positif dalam pemahaman konsep dan kreatifitas seseorang, oleh karena itu kemampuan ini sangat diperlukan siswa, namun terdapat banyak masalah siswa ketika dalam pembelajaran memecahkan masalah matematis. Siswa dalam pembelajarn terkadang bingung untuk menyelesaikan soal. Menurut Russeffendi (2006), Kemampuan pemecahan masalah amatlah penting dalam matematika, bukan saja bagi mereka yang di kemudian hari akan mendalami atau mempelajari matematika, melainkan juga bagi mereka yang akan menerapkannya dalam bidang studi lain dan dalam kehidupan seharihari. Dalam pembelajaran dibutuhkan inovasi untuk mengembangkan kemampuan pemecahan masalah siswa dengan menciptakan suatu pembelajaran bermakna bagi siswa. Adanya inovasi dari metode dan cara menyajikan materi pelajaran diharapkan dapat berpengaruh terhadap peningkatan kemampuan pemecahan masalah matematis siswa. Dengan kata lain, pembelajaran matematika di kelas perlu menyentuh aspek pemecahan masalah siswa yang dilakukan secara sengaja dan terencana.

Dari hasil penelitian Oktaviana (2017) hasil analisis data diperoleh bahwa, kemampuan pemecahan masalah matematik siswa pada siklus I diperoleh 15 siswa $(57,69 \%)$ dari 26 siswa yang mengalami peningkatan kemampuan pemecahan masalah matematik, sedangkan pada siklus II meningkat menjadi 23 siswa $(88,46 \%)$ dari 26 siswa, sehingga dapat disimpulkan untuk meningkatkan kemampuan pemecahan masalah matematis siswa, digunakanlah model pembelajaran LAPS-Heuristik. Komala (2016), model pembelajaran 
Laps-Heuristik adalah model pemecahan masalah matematika yang menekankan pada pencarian alternatif-alternatif yang berupa pertanyaan-pertanyaan yang dapat digunakan untuk pemecahan masalah. Heuristik berfungsi untuk mengarahkan pemecahan masalah siswa dalam pemecahan masalahnya. Menurut Susanti, dkk (2016) menyatakan bahwa model LAPS-Heuristik memfasilitasi siswa untuk menyeselaikan permasalahan non rutin. Masalah non rutin ini memberikan kesempatan kepada siswa untuk menyelesaikan masalah didefinisikan suatu persoalan yang tidak rutin belum dikenal cara penyeselaiannya, kemudian dicari jalan keluar untuk mengetahui kunci untuk mencari atau menemukan cara penyelesaian.

Berdasarkan uraian yang telah dikemukakan sebelumnya, penelitian ini difokuskan pada peningkatan pemecahan masalah matematis siswa dengan menggunakan model pembelajaran LAPS-Heuristik. Penelitian ini penting dilakukan untuk mengetahui apakah dengan menggunakan model pembelajaran LAPS-Heuristik dapat meningkatkan kemampuan pemecahan masalah matematis siswa serta menjawab rumusan masalah. Tujuannya sehingga setelah menggunakan model pembelajaran LAPS-Heuristik siswa dapat meningkatkan kemampuan pemecahan masalah matematis.

\section{Metode Penelitian}

Metode yang digunakan dalam penelitian ini adalah metode quasi eksperimen, karena dalam penelitian ini diberikan suatu perlakuan untuk mengetahui pengaruh antara perlakuan dengan aspek tertentu yang akan diukur. Faktor berupa perlakuan yang diberikan pada faktor lain yang diukur akan terlihat hasilnya pada penelitian eksperimen. Perlakuan dalam penelitian ini adalah pembelajaran dengan meggunakan model LAPS-Heuristik sedangkan aspek yang diukurnya adalah kemampuan pemecahan masalah matematis siswa. Oleh karena itu yang menjadi variabel bebas dalam penelitian ini adalah model LAPSHeuristik sedangkan yang menjadi variabel terikatnya adalah kemampuan pemecahan masalah matematis siswa.

Desain yang digunakan dalam penelitian ini yaitu desain The Non equivalent Pre test-Post test Control Group Design. Dalam desain ini terdapat dua kelompok yaitu kelas eksperimen dan kelas kontrol. Teknik pengambilan sampel menggunakan purposive sampling. Pada tahap awal keduanya diberikan pre test (tes awal) untuk mengetahui kemampuan awalnya. Kemudian untuk kelas eksperimen diberikan perlakuan khusus yaitu menggunakan model LAPS-Heuristik, sedangkan kelas kontrol sebagai pembanding menggunakan pembelajaran biasa. Kemudian pada tahap akhir keduanya diberikan post test (tes akhir) dan dibandingkan peningkatannya. Sampel adalah sebagian atau wakil populasi yang diteliti (Arikunto, 2010). Cara pengambilan sampel dalam penelitian sangatlah penting terlebih jika peneliti ingin hasil penelitinya berlaku untuk seluruh populasi. Sehingga sampel yang diambil haruslah dapat mewakili semua karakteristik yang terdapat pada populasi jika tidak maka kesimpulannya dari penelitiannya bias. Adapun yang dijadikan sampel dalam penelitian ini adalah kelas IPA 2 sebagai kelas eksperimen dan kelas IPA 1 sebagai kelas kontrol.

Proses pengumpulan data dengan cara siswa diberikan tes dan non tes. Tes terdiri dari tes kemampuan pemecahan masalah matematis siswa diberikan saat pre test dan post test untuk mengetahui peningkatan kemampuan pemecahan masalah matematis, sedangkan non tes 
terdiri dari kuesioner (angket) untuk mengetahui sikap siswa terhadap model pembelajaran LAPS-Heuristik.

Pengolahan analisis data yaitu dari data pre test, post test dan indeks gain. Uji normalitas pre test digunakan untuk mengetahui apakah data hasil pre test berasal dari populasi yang berdistribusi normal atau tidak berdistribusi normal. Jika setelah diuji data hasil pre test berdistribusi normal maka untuk menguji kesamaan dua ratarata menggunakan statistik parametrik. Sedangkan jika kedua data atau salah satu data tidak berdistribusi normal, maka uji kesamaan dua rata-rata menggunakan statistik non parametrik (Mann Whitney).

$\mathrm{Uji}$ homogenitas pre test dilakukan untuk mengetahui apakah data hasil pre test berasal dari populasi yang memiliki varians homogen atau tidak. Jika data yang diperoleh berdistribusi normal dan homogen maka dilanjutkan dengan uji-t, sedangkan jika ada data yang diperoleh berdistribusi normal namun tidak homogen maka dilanjutkan dengan uji-t'.

Uji kesamaan dua rata-rata dilakukan untuk melihat apakah data hasil pre test dari kelas eksperimen dan kelas kontrol memiliki hasil yang sama atau tidak. Jika data berdistribusi normal dan memiliki varians yang homogen maka pengujiannya menggunakan uji $\mathrm{t}$ (independent sample $t$ test). Jika data berdistribusi normal dan tidak memiliki varians yang homogen maka pengujiannya menggunakan uji t' (independent sample t' test).

Uji Mann Whitney dilakukan jika salah satu atau semua data berdistribusi tidak normal. Kemudian untuk melihat peningkatan kemampuan pemecahan masalah dengan menggunakan model LAPS-Heuristik dapat dilihat dari indeks gain dengan rumus:

Indeks gain $=\frac{\text { skor posttest }- \text { skor pretest }}{\text { skor ideal }- \text { skor pretest }}(1)$

\section{Hasil dan Pembahasan}

Penelitian tentang pembelajaran matematika dengan menggunakan model LAPS-Heuristik pada kelas eksperimen dilaksanakan sebanyak 5 kali pertemuan dan pada kelas kontrol menggunakan pembelajaran biasa sebanyak 5 kali pertemuan.

Pada pertemuan pertama peneliti memberi pre tes pada kelas eskperimen dan kelas kontrol untuk mengetahui kemampuan awal yang dimiliki siswa sebelumnya. Kemudian dilakukan pengujian dan analisis data dengan tujuan untuk mengetahui kemampuan awal pemecahan masalah matematis siswa dari kedua kelas tersebut. Kemudian dilakukan pengujian dan analisis data dengan tujuan untuk mengetahui kemampuan awal pemecahan masalah matematis siswa dari kedua kelas tersebut.

Tabel 1. Data Hasil Pretes

\begin{tabular}{ll}
\hline \multicolumn{2}{c}{ Data Pretes } \\
\hline $\begin{array}{l}\text { Asymp. Sig (2- } \\
\text { tailed) }\end{array}$ & bKeterangan \\
\hline 0,085 & $\mathrm{H}_{0}$ diterima \\
\hline
\end{tabular}

Dari Tabel 1 dapat dilihat nilai signifikansi 0,085 . Nilai tersebut lebih besar dari 0,05 sehingga $\mathrm{H}_{0}$ diterima. Dengan demikian dapat disimpulkan bahwa kemampuan awal pemecahan masalah matematis kelompok eksperimen dan kelompok kontrol sama, dalam artian jika kelas eksperimen rata-rata nilai pre tesnya 70 maka kelas kontrolpun rata-rata nilai pre tesnya 70 . Oleh karena kemampuan kedua kelas sama maka penelitian dapat dilanjutkan dengan memberikan perlakuan yang berbeda.

Dalam kegiatan pembelajaran matematika dengan model LAPSHeuristik hal yang dilakukan adalah mengawali dengan doa dan memerksa kehadiran. Pada kelompok eksperimen dimulai dengan peneliti mengingatkan materi sebelumnya sebagai prasyarat 
pada siswa. Kemudian peneliti membagi siswa menjadi beberapa kelompok yang terdiri dari 5 atau 6 orang dalam satu kelompoknya. Setelah itu peneliti membagikan lembar aktivitas siswa (LAS) kemasing-masing kelompok untuk diselesaikan, adapun isi dari LAS tersebut yaitu berupa permasalahan dan tahapan penyelesaian serta latihan soal kemampuan pemecahan masalah matematis siswa, untuk tahapan penyelesaian dari suatu masalah berupa tahapan model pembelajaran LAPSHeuristik diantaranya yaitu, memahami masalah, merencanakan permasalahan, merencanakan masalah sesuai rencana langkah kedua (solusi), memeriksa kembali hasil yang diperoleh (looking back).

Setelah siswa menyelesaikan masalah pada LAS dengan melalui tahapan penyelesaian maka beberapa perwakilan dari kelompok mempresentasikan hasil diskusinya. Kemudian siswa mengisi latihan soal kemampuan pemecahan masalah matematis pada LAS setelah itu perwakilan dari beberapa kelompok mempresentasikan jawaban latihannya. Kemudian di akhir pembelajaran penelitian dan siswa menyimpulkan hasil pembelajaran.

Sedangkan pembelajaran biasa pada kelompok kelas kontrol, guru tidak memberikan perlakuan apapun sehingga pembelajaran dilakukan dengan model yang sudah biasa dilakukan oleh guru disekolah tersebut. Kedua kelompok diberikan materi yang sama yaitu trigonometri.

Pada pertemuan terakhir peneliti memberi post tes pada kelas eksperimen dan kelas kontrol untuk mengetahui kemampuan pemecahan masalah matematika. Adapun aspek kemampuan pemecahan masalah matematika siswa pada penelitian ini yaitu:

1. Memahami masalah
2. Merencanakan permasalahan

3. Merencanakan masalah sesuai rencana langkah kedua (solusi)

4. Memeriksa kembali hasil yang diperoleh (looking back).

Tabel 2. Data Hasil Postes

\begin{tabular}{cc}
\hline \multicolumn{2}{c}{ Indeks Gain } \\
\hline $\begin{array}{c}\text { Asymp. Sig } \\
\text { (2-tailed) }\end{array}$ & Keterangan \\
\hline 0,004 & $\mathrm{H}_{0}$ ditolak \\
\hline
\end{tabular}

Dari Tabel 2 dapat dilihat setengah dari nilai signifikansi (2-tailed) sebesar 0,004 . Nilai tersebut kurang dari 0,05 sehingga $\mathrm{H}_{0}$ ditolak. Dengan demikian dapat disimpulkan bahwa rata-rata peningkatan kemampuan pemecahan masalah matematis dengan menggunakan model pembelajaran LAPS-Heuristik pada pembelajaran matematika lebih baik dari pada kemampuan pemecahan masalah matematis yang menggunakan model pembelajaran biasa.

Hal ini sejalan dengan penelitian dari Oktaviana (2017) bahwa dengan model LAPS-Heuristik diperoleh peningkatan dalam pemecahan masalah matematis, terbukti dilihat dari sinklus 1 dan 2, dan hasilnya meningkat atau positif. Kemudian menurut Rahman (2018) bahwa dengan model pembelajaran LAPS-Heuristik dapat meningkatkan pemecahan masalah dibandingkat dengan pembelajaran menggunakan konvesional.

Dapat kita simpulkan bahwa dengan menggunakan model LAPSHeuristik dapat membuat siswa meningkat dalam pemecahan masalah dalam belajar karena langkah-langkah dari pembelajaran LAPS-Heuristik memudahkan siswa dalam menyelesaikan soal non rutin atau soal tingkat tinggi yang akhrinya siswa bisa meningkatkan kemampuan pemecahan masalah.

Analisis hasil data kuesioner dilakukan dengan tujuan untuk melihat sikap siswa terhadap pembelajaran 
matematika dengan menggunakan model pembelajaran LAPS-Heuristik. Kuesioner sikap siswa yang diberikan terdiri dari 20 butir pernyataan, dengan 13 butir pernyataan positif dan 7 butir pernyataan negatif. Pernyataan kuesioner terhadap pembelajaran matematika, sikap siswa terhadap model pembelajaran LAPSHeuristik dan terhadap kemampuan pemecahan masalah matematika.

Adapun sikap siswa terhadap pembelajaran matematika, model LAPSHeuristik, dan kemampuan pemecahan masalah matematis siswa.

Tabel 3. Persentasi Keseluruhan Sikap Siswa

\begin{tabular}{|c|c|c|c|}
\hline \multirow[t]{2}{*}{ Aspek } & \multicolumn{2}{|c|}{$\begin{array}{l}\text { Rata-rata } \\
\text { Persentase }\end{array}$} & \multirow[t]{2}{*}{$\begin{array}{c}\text { Ketera } \\
\text { ngan }\end{array}$} \\
\hline & $\begin{array}{l}\text { Sikap } \\
\text { Positif }\end{array}$ & $\begin{array}{c}\text { Sikap } \\
\text { Negatif }\end{array}$ & \\
\hline $\begin{array}{l}\text { Sikap } \\
\text { siswa } \\
\text { terhadap } \\
\text { matemati } \\
\text { ka }\end{array}$ & 52,68 & 47,32 & $\begin{array}{c}\text { Sebagian } \\
\text { Besar } \\
\text { Positif }\end{array}$ \\
\hline $\begin{array}{l}\text { sikapsiswa } \\
\text { terhadap } \\
\text { model } \\
\text { pembelaja } \\
\text { ran LAPS- } \\
\text { Heuristik }\end{array}$ & 63,84 & 36,16 & $\begin{array}{c}\text { Sebagian } \\
\text { Besar } \\
\text { Positif }\end{array}$ \\
\hline $\begin{array}{l}\text { Sikap } \\
\text { siswa } \\
\text { terhadap } \\
\text { kemampu } \\
\text { an } \\
\text { pemecahan } \\
\text { masalah } \\
\text { matematis }\end{array}$ & 76,34 & 23,66 & $\begin{array}{c}\text { Sebagian } \\
\text { Besar } \\
\text { Positif }\end{array}$ \\
\hline Rata-rata & 64,28 & 35,72 & $\begin{array}{l}\text { Sebagian } \\
\text { Besar } \\
\text { Positif (19 } \\
\text { orang dari } \\
28 \text { orang) }\end{array}$ \\
\hline
\end{tabular}

Berdasarkan Tabel 3 dapat dilihat dari rata-rata total persentase sikap siswa yang diperoleh pada sikap positif yaitu sebesar 64,28 \% yang menunjukkan bahwa sebagian besar sikap siswa adalah positif. Sehingga dapat disimpulkan bahwa sebagian besar siswa memberikan sikap positif pada pembelajaran matematika dengan menggunakan model pembelajaran LAPS-Heuristic.

\section{Kesimpulan}

Berdasarkan dari hasil dan pembahasan dari data penelitian diperoleh kesimpulan bahwa peningkatan kemampuan pemecahan masalah matematis siswa dengan menggunakan model pembelajaran LAPS-Heuristic lebih baik dari pada kemampuan pemecahan masalah matematis siswa dengan model pembelajaran biasa karena model pembelajaran LAPS-Heuristik langkah-langkah pembelajarannya lebih tersusun dan sangat jelas serta cocok untuk kemampuan pemecahan masalah matematis siswa dibandingkan dengan model pembelajaran yang lain.

Sikap siswa terhadap pembelajaran matematika dengan menggunakan model LAPS-Heuristic sebagian besar postif.

\section{Daftar Rujukan}

Abdurrahman, Mulyono. (2003). Pendidikan Bagi Anak Berkesulitan Belajar. Jakarta:PT Rineka Cipta.

Arikunto, S. (2010). Prosedur Penelitian. Jakarta: PT Rineka Cipta.

Komala, Elsa. (2016). Penelitian Pendidikan Matematika.Cianjur: Universitas Suryakancana.

National Council of Teachers of Mathematics (NCTM).(2000). Executive SummaryPrinciples and Standards for School Mathematics. Reston, USA:NCTM,Inc. Tersedia: https://www.nctm.org/uploadedFile s/Standards_and_Positions/PSSM_ ExecutiveSummary.pdf.

Purba, Oktaviana Nirmala, Syahriani Sirait. (2017). "Peningkatan Kemampuan Pemecahan Masalah Pada Materi Trigonometri dengan Model Laps-Heuristic pada Kelas X SMA Syafiyyatul Amaliah" Dalam 
Proseding Seminar Nasional Multidisiplin Ilmu UNA [ offline], volume 2 (1) 13 halaman. Tersedia:https://osf.10/preprints/ina rXIV/fhq3e/

Rahman, Irasilviana, Nerru Pranuta Murnakadan Wiwik Wiyanti. (2018). "Pengaruh Model Pembelajaran Laps(Logan Avenue Problem Solving)-Heuristic Terhadap Kemampuan Pemecahan Masalah" Dalam Wacana Akademi [ offline], volume2 (1) 13 halaman. Tersedia:http://www.jurnal.ustjogja .ac.id/indexphp/wacanaakademik/article/view/2 556

Ruseffendi, E, T. (2006).Pengantar Kepada Membantu Guru Mengembangkan Kompetensinya dalam Pengajaran Matematika untuk Meningkatkan CBSA. Bandung: Tarsito.
Susanti, Witna, Andri Novianto dan Mira Amelia Amri. (2016). "Kemampuan Pemecahan Masalah Matematika Siswa Melalui Model Pembelajaran LAPS-Heuristic Di Kelas X SMA N 2 Batang Anai" Dalam JURNAL GANTANG Pendidikan Matematika FKIP[online], Vol. 1 (2) 12 halaman. Tersedia: https://ojs.umrah.ac.id/index.php/ga ntang/article/view/52/42.

Yulianto, Gogot Dwi, Ketut Suastika dan Tridja Fayeldi. (2019). "Analisis Kemampuan Pemecahan Masalah Matematika Berdasarkan Langkah Polya Pada Materi Sistem Permamaan Linier Dua Variabel" Dalam Pi: Mathematisc Education Journal[ofline], Vol. 2 (01) 7 halaman. Tersedia: http://ejournal.unikama.ac.id/index. php/pmej/index 